Printed in Great Britain

\title{
Additional data on the population distribution of human serum albumin genes; three new variants
}

\author{
By L. R. WEITKAMP,* E. M. MoDERMID, † J. V. NEEL $\ddagger$, J. M. FINE,§ C. PETRINI,\| \\ L. BONAZZIף V. ORTALI,** F. PORTA, †† R. TANIS, $\ddagger$ D. J. HARRIS, \\ T. PETERS,§§ G. RUFFINI, †† AND E. JOHNSTON*
}

Recently we have presented an electrophoretic comparison of genetically determined human serum albumin variants from diverse populations, distinguishing 20 different types of 'monomeric' variants as well as three 'dimeric' variants (Weitkamp et al. 1973; Weitkamp \& Neel, 1972). At this time we compare the 20 previously described types of monomeric variants with 30 more variants, generally rare, and extend our data and conclusions on the population distribution of albumin variants.

\section{MATERLALS AND METHODS}

Each albumin variant, its source, and ethnic origin are listed in the Appendix. Many of the new variants were found in several individuals in a single family. In other cases the variants were found in one or more individuals in a single village. The electrophoretic comparisons were made in the three starch-gel systems, acetate-EDTA at $\mathrm{pH} 5 \cdot 0$, tris-lithium-succinate-citrate at $\mathrm{pH} 6.0$ and tris-EDTA-borate at $\mathrm{pH} 6 \cdot 9$, used previously (Weitkamp et al. 1973).

\section{RESULTS}

The results of the comparison of 30 new or recently described serum albumin variants with 20 variants previously distinguished using three starch-gel electrophoretic systems are presented in Table 1. Although the amount of separation reported here for the 20 variants previously described differs slightly from the earlier results, due to minor variations in electrophoretic conditions, the conclusions regarding their mobility relative to normal albumin and to each other remain the same. Three new variants, RS I, Xavante, and Yanomama-2, all slowly migrating, have been identified. Electropherograms showing these variants adjacent to variants with similar mobility are presented in Fig. 1.

Albumin RS I, found in an indigene from Somali, has been mentioned in two previous reports. Porta et al. (1972) found it (identified as R.S.) indistinguishable from SO/BS on cellulose acetate electrophoresis at $\mathrm{pH}$ 9.25. The sample available at the time of our prior comparison (Weitkamp et al. 1973) was sufficiently degraded, as determined by the smeared patterns in the $\mathrm{pH} 6.0$ and 6.9 systems and the altered mobility of normal albumin in the $\mathrm{pH} 5 \cdot 0$ system, to preclude determination of its mobility. In the present sample, both the normal and variant albumin bands stain less intensely with Amido Black 10B than the albumin bands

* University of Rochester School of Medicine and Dentistry, Rochester, New York.

$\dagger$ John Curtin School of Medical Research, Canberra City, Australia.

‡ University of Michigan Medical School, Ann Arbor, Michigan.

$\S$ Centre National de Transfusion Sanguine, Paris. \| Ospedale Maggiore S. Carlo Borromeo, Milan.

9 Civil Major Hospital, Verona, Italy.

†† Ospedale Civile, Sondrio, Italy.

** Istituto Superiore Sanità, Rome.

$\S \S$ Mary Imogene Bassett Hospital, Cooperstown, New York. 


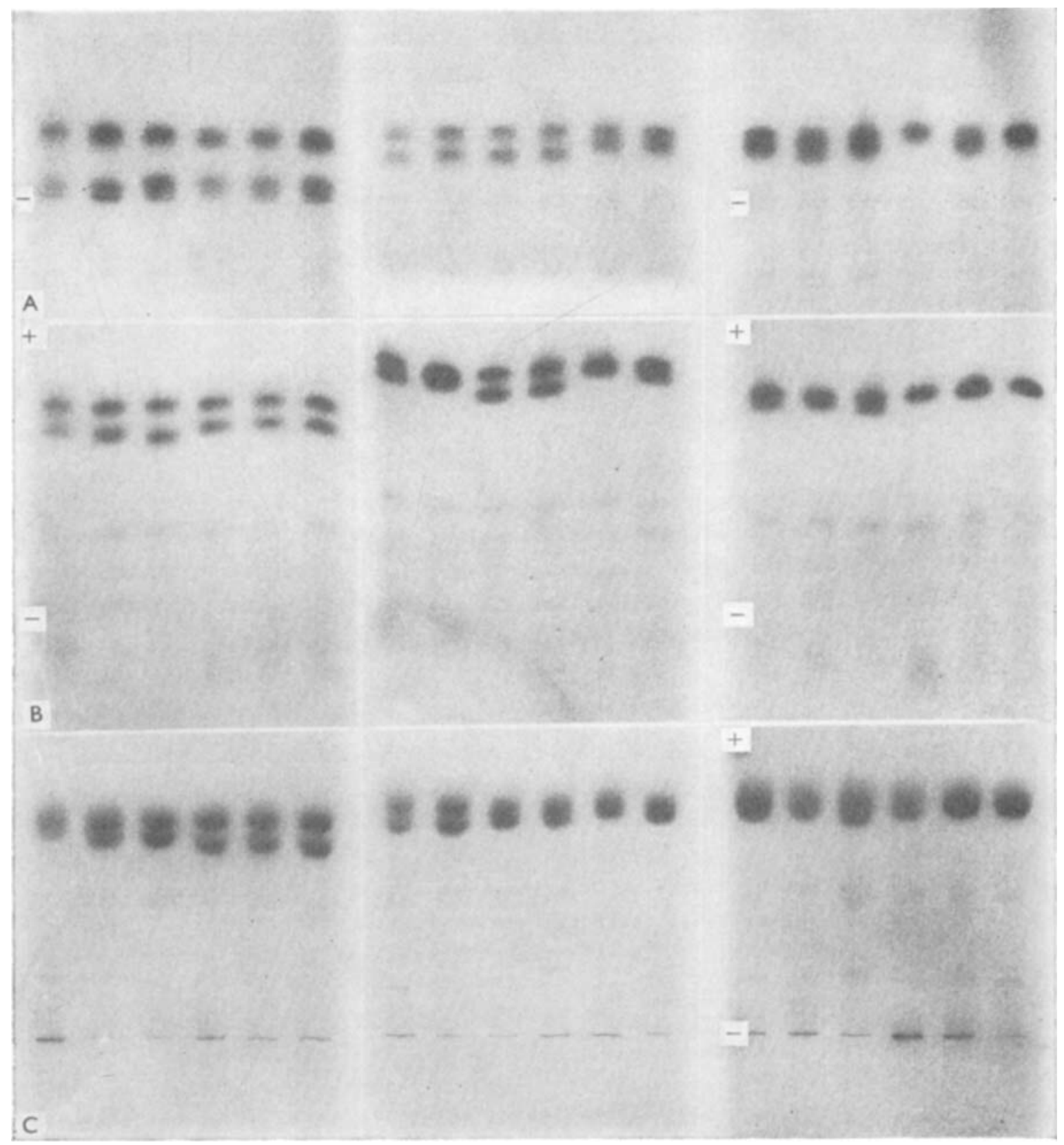

Fig. 1. Comparative mobility of human serum albumin variants. Vertical starch-gel electrophoresis of serum in three buffer systems. Origin is indicated by a dash; anode is at the top. Gels A: acetateEDTA, pH 5.0. Gels B: tris-lithium-succinate-citrate, pH 6.0. Gels C: tris-EDTA-borate, pH 6.9. From left to right: (1) RS I; (2) Pollibauer; (3) Bélem I; (4) 4014; (5) B (family 10); (6) 4014; (7) Santa Ana; (8) SO/BS; (9) Etie; (10) Cartago; (11), Xavante; (12) Pushtoon; (13) Pushtoon; (14) Cayemite; (15) Mexico; (16) Yanomama-2; (17) Uinba; (18) normal serum. 
in other sera, presumably due to a low concentration of albumin. Nevertheless, there is no deterioration in the sharpness of the bands in the $\mathrm{pH} 5.0$ and 6.0 systems - systems in which RS I is clearly distinguishable from SO/BS but is indistinguishable from albumin Pollibauer. In the $\mathrm{pH} 6.9$ system the pattern is somewhat blurred, as is the case with a number of variants in this buffer system. However, on repeated examination at $\mathrm{pH} 6.9 \mathrm{RS} \mathrm{I}$ is not as slowly migrating as Pollibauer and thus appears to be a new variant.

Albumin Xavante, a variant found in Xavante Indians of the Brazilian Mato Grosso, is similar to albumin Pushtoon in the $\mathrm{pH} 5.0$ system. In the $\mathrm{pH} 6.0$ system it is clearly different from Pushtoon and indistinguishable from normal albumin. The Xavante variant can also be distinguished from Pushtoon in the $\mathrm{pH} \mathrm{6.9} \mathrm{system,} \mathrm{the} \mathrm{difference} \mathrm{in} \mathrm{mobility} \mathrm{being} \mathrm{more}$ apparent than is indicated in Table 1 if electrophoresis is continued for a longer time. Since albumins Xavante and Uinba are indistinguishable from normal albumin in the $\mathrm{pH} 6.0$ and 6.9 systems, it should be emphasized that the electrophoretic separations shown in Table 1 and in Fig. 1 for the $\mathrm{pH} 5.0$ system are from different gels and that on the same $\mathrm{pH} 5 \cdot 0$ gel the two variants are clearly distinguishable. The Xavante variant was found in two of 214 tested individuals from São Marcos village (for location and description see Salzano, Neel \& MayburoLewis, 1967). Two additional samples in the 214 had a blurred albumin pattern which could not be definitely typed, but are probably further samples of the Xavante variant. None of the four individuals were known to be related. Another 245 people in two other Xavante villages (São Domingos and Simões Lopes) had only normal albumin.

Albumin Yanomama-2 is clearly different from normal albumin only in the $\mathrm{pH} 6.9$ system, a feature which distinguishes it from other variants. Thus far, it has been found in 47 individuals (including one homozygote) from three Yanomama villages in northern Brazil (Tanis et al. 1973). However, the fact that it is indistinguishable from normal albumin in two of the three buffer systems and only slightly different from normal in the third suggests the possibility that it could have been overlooked in previous surveys of albumin variants in Amerindians.

The remaining 27 variants were indistinguishable from previously described variants. Twentytwo of the variants were found in Europeans or individuals of European descent, each of the variants being indistinguishable from variants previously found in Europeans. The variants found in widely separated indigenous villages in New Guinea are indistinguishable from each other and from a variant previously found in New Guinea indigenes. The remaining two variants, also indistinguishable from each other, were found in Hindus of different caste and were indistinguishable from a variant previously found in a Moslem family from Kashmir and in a Pushtoon village in Afghanistan.

\section{DISCUSSTON}

Only seven of the 20 previously described types of monomeric albumin variants - Pollibauer, B, Roma, Gainesville, SO/BS, Cartago and Gent-were found exclusively in individuals of European descent. And only three of these types - B, Gainesville and Gent - had been found in more than one family. All of the variants were rare, having a collective frequency of less than 1 in 1000 (cf. table 3, Weitkamp et al. 1973). Thus, it is noteworthy that 22 of the 23 variants found by the current collection in individuals of European descent are indistinguishable from one of six types of variants previously found exclusively in Europeans. The nineteenth variant, albumin Westcott, was traced to an ancestor thought to be three-quarters English and one- 
quarter American Indian. This variant was indistinguishable from albumin Reading (New Guinea), a variant previously found in three families of European descent as well as in New Guinea indigenes. If rare albumin variants were haphazardly distributed through all populations, one would predict that some of the 23 new variants found in Europeans might resemble one of the many types of new variants not previously found in Europeans but known to be distinguishable from normal albumin. The distribution, in fact, appears to be less than haphazard (for discussion see Weitkamp, 1973).

The occurrence of uncommon albumin variants in non-European populations also does not appear to be random. McDermid (1971a) found three variants, indistinguishable from each other in the $\mathrm{pH} \mathrm{5.0}$ and 6.9 systems, among 1508 individuals from five Indian populations, including Bombay, Madras, New Delhi, Singapore and South Africa (Natal). The variants were found in two Hindus of different caste from New Delhi and in one individual from South Africa. Sera from the two New Delhi residents are compared in the present paper; they are indistinguishable from each other and from albumin Afghanistan, a variant from a Pushtoon tribe originating in East Afghanistan. The Afghanistan variant was previously shown to be indistinguishable from albumin Kashmir. This variant has not been found in other groups. We are aware of only one other report of an albumin variant in India (Atal, Mital \& Kulshretha, 1970), in a Hindu from Agra. It was not possible to obtain a sample of this variant, but the variant is slowly migrating and on cellulose acetate electrophoresis sufficiently separated from normal albumin to suggest a mobility similar to that of Kashmir. One cannot rule out the possibility that the Kashmir variant may prove to be polymorphic in some populations in this area. At the moment, however, the observation is that albumin Kashmir has been found in several different populations, all in the Indo-Dravidian group, and that at least among Indians it appears uncommon.

Albumin New Guinea was initially found in 7 of 724 individuals from 44 widely scattered indigenous villages in New Guinea (Weitkamp, Shreffler \& Saave, 1969). The 7 individuals were located in three widely separated villages: 2 among 35 people in a village $\left(6^{\circ} 10^{\prime} \mathrm{S}\right.$ and $146^{\circ} 12^{\prime}$ $\mathrm{E})$ in the Eastern Highlands, 1 among 45 individuals from a village $\left(8^{\circ} 38^{\prime} \mathrm{S}\right.$ and $\left.148^{\circ} 12^{\prime} \mathrm{E}\right)$ near Popondetta on the south-eastern end of the northern coast, and 4 among 31 people from Rossel Island $\left(11^{\circ} 21^{\prime} \mathrm{S}\right.$ and $\left.154^{\circ} 16^{\prime} \mathrm{E}\right)$ at the eastern end of the Louisade Archipelago. Subsequently McDermid (1971 b), using the same electrophoretic conditions, found one variant, similar in mobility to albumin New Guinea, among 595 individuals from nine areas. This variant, identified as MAP in Table 1, is not distinguishable from the New Guinea variant in any of the three buffer systems. It was found among 39 individuals in the Maprik district $\left(3^{\circ} 38^{\prime} \mathrm{S}\right.$ and $143^{\circ}$ $\left.4^{\prime} \mathrm{E}\right)$ on the western end of the northern coast of New Guinea, an area widely separated from the three previously described villages. MeDermid (unpublished observations, 1973) has also examined another 1307 indigenes, primarily from the Eastern highlands and adjacent coastal area to the north including Kar Kar Island and from the southern coast, both near Port Moresby and at the eastern end of the peninsula. Seven individuals with an albumin variant were found among 325 individuals tested in Pari village $\left(9^{\circ} 30^{\prime} \mathrm{S}\right.$ and $\left.147^{\circ} 10^{\prime} \mathrm{E}\right)$, near Port Moresby. This variant, identified as PAR in Table 1 , is also indistinguishable from albumin New Guinea. Thus, a fifth source of the New Guinea variant, widely separated from the other four, has been located. Including an additional 183 individuals from Manus Island (Malcolm et al. 1972), 15 examples of the New Guinea variant have now been found among 2809 individuals, all of whom

1 Corrected from $146^{\circ} 12^{\prime} \mathrm{E}$. 
are located within the circumference of a circle whose diameter of more than 900 miles is determined by the two most distal points at which the variant was found.

The genetic basis for the frequency of the New Guinea variant in New Guinea indigenes is unknown, but the following conclusions appear reasonable. First, the gene frequency of the variant is low - perhaps lower than the $1 \%$ usually accepted for polymorphism. An exact frequency cannot be computed since the relatedness of the tested individuals is unknown. However, assuming that individuals with and without the variant have an equal degree of relatedness, the gene frequency of the variant is 1 in 400 . Even considering only the villages in which the variant has been observed the gene frequency is no more than 1 in 60 , scarcely three times the mean number of genes examined in each village. Secondly, given the fact that the variant has been found at five widely separated points, it seems unlikely that the frequency is accounted for by random genetic forces, such as the founder effect, lineal effect or headmanship effect observed in some primitive populations (Chagnon et al. 1970), although in the absence of historical data this possibility cannot be ruled out.

The finding of two new variants among American Indians must partially reflect the fact that this group has been extensively and carefully studied for albumin variation, following the early finding of polymorphism at this locus among the Naskapi (Melartin \& Blumberg, 1966). Nevertheless, the genetic variability of serum albumin in the American Indian is striking (cf. Weitkamp et al. 1973). Out of a total of 26 types of variants, the three clearly polymorphic variants (Naskapi, Mexico and Makiritare) are all of Amerindian origin. Another four variants (Yanomama, Yanomama-2, Makiritare-3 and Xavante) have been found only in American Indians. Albumin Máku is probably of Indian origin, having been found in the Yanomama and Makiritare as well as in a Brazilian trihybrid group. Albumin Santa Ana and Belém I were found in a Mexican family and a Brazilian trihybrid group, respectively, and may possibly be Indian in origin. Thus, eight to ten of 26 types of variants have been found in American Indians. Albumin variability in the Yanomama and Makiritare, where five types of variants have now been found, stands in marked contrast to the relative infrequency of albumin variants in Europeans, if one considers the relative lack of variation in other protein systems for these Indians compared to Europeans (Weitkamp \& Neel, 1972).

\section{SUMMARY}

Thirty additional electrophoretic variants of serum albumin have been compared in three starch-gel systems previously used to distinguish 20 different types of inherited 'monomeric' albumin variants. Three new types are reported, of which two occur in American Indians and one in a Somali indigene. The 27 remaining variants include 8 different types, indistinguishable from 8 of the 20 types previously reported. Twenty-three of the 27 variants came from individuals of European descent, 2 came from New Guinea indigenes and 2 were from Hindus of different caste in India. The 23 rare variants found in Europeans all correspond to types previously found in Europeans and include 7 of the 9 types of monomeric variants previously identified as European in origin. The variant found in New Guinea indigenes is indistinguishable from a low-frequency, variant previously reported in this population. Similarly the uncommon variant found in two Hindus is indistinguishable from a variant found in other groups in the Indo-Dravidian population.

This work was supported in part by U.S. National Institutes of Health Research Career Development Award 5K04HD 50248 (L.R.W.) 


\section{NOTE ADDED IN PROOF}

Since the preparation of this manuscript, Porta et al. (1973) have described an electrophoretic comparison of $\mathbf{3 7}$ albumin variants from Italy or Somali using cellulose acetate electrophoresis at $\mathrm{pH} 8 \cdot 6$ to $9 \cdot 25$. Among the 37 variants were included one of the Somali variants (RS III) and the 12 Italian variants in the present series as well as the Roma variant of the previous series (cf. Table 1). Porta et al. felt that virtually all of the 37 variants from unrelated individuals had, in contrast to variants from related individuals, slightly different electrophoretic mobility. They did, however, distinguish four general 'groups' of variants, one rapidly migrating and 3 slowly migrating. All 4 groups are represented in the 14 variants included in both comparisons, and among these we have distinguished six types (No. 2, 4, 5, 10, 11 and 23 in Table 1) using 3 different acid starch gel systems.

In Table 1 albumins Pollibauer, RS III, MI/MI 4 and 3366 are listed as indistinguishable, although small differences in mobility were noted in the $\mathrm{pH} 5.0$ and 6.9 systems. If the results of Porta et al. are added to our results, it appears that at least one more type of variant can be recognized. Since RS III is more slowly migrating than MI/MI 4 on alkaline cellulose acetate electrophoresis (Porta et al. 1973), and the two variants have in addition small differences in mobility in the starch-gel systems, we believe that a 24th type of variant has probably been demonstrated. We do not know whether Pollibauer and 3366 will resemble RS III or MI/MI 4 in the cellulose acetate system, but propose, both on the basis of the mobilities listed in Table 1 and on the fact that RS III was found in Somali whereas the other 3 variants were found in Europe, that the designation for the new type of variant be RS III and that Pollibauer be retained as the type designation applying to the variants Pollibauer, MI/MI 4 and 3366.

The four variants of Italian origin [SO/SO(Gi.Pa.), VR/VR(Ag.Di.), VR/VR(Bi.Gi.), VR/VR (Pi.Al.)] listed as type B in Table 1 were also included in two different groups by Porta et al. We have followed a policy of accepting two variants as being electrophoretically distinguishable only if there are small, consistent differences in several electrophoretic systems or if the difference in one particular system is large. Since the classification by Porta et al. was in this case into two groups of slightly different mobility and since no difference was observed in the starch gel systems, we suggest that these 4 variants should not be considered to represent more than one type. It is worth recalling that not all albumin variants from unrelated individuals are in fact different since at least two and probably three B type variants have similar peptide maps, differing from normal by the same single amino acid substitution (reviewed in Porta et al. 1973 and Weitkamp et al. 1973).

\section{REFERENCES}

Atal, P. R., Mrtal, V. P. \& Kulshrestha, R. C. (1970). Heterogeneity of human serum albumin. Report of a case of bisalbuminemia. Ind. J. Med. Sci. 12, 797.

Chagnon, N. A., Neel, J. V., Weitkamp, L., Gershowitz, H. \& Ayres, M. (1970). The influence of cultural factors on the demography and pattern of gene flow from the Makiritare to the Yanomama Indians. Am. J. Phys. Anthrop. 32, 339.

Fine, J. M. (1970). Les allotypes de l'albumine humaine. Etude de 8 cas de bisalbuminémie observés en France. Rev. Europ. Etudes Clin. Biol. 15, 113.

HarRIS, H. (1970). Human Biochemical Genetics, p. 215. Amsterdam: North-Holland.

Malcolm, L. A., Woopfield, D. G., Blake, N. M., KIRK, R. L. \& McDermid, E. M. (1972). The distribution of blood, serum protein and enzyme groups on Manus Island (Admiralty Islands, New Guinea). Hum. Hered. 22, 305. 
MoDERMID, E. M. (1971a). Serum albumin variation in Indian populations. Vox Sang. 21, 462.

MoDERMID, E. M. (1971b). Variants in human serum albumin and ceruloplasmin in populations from Australia, New Guinea, South Africa and India. Aust. J. Exp. Biol. Med. Sci. 49, 309.

Melartin, L. \& Blumberg, B.S. (1966). Albumin Naskapi: A now genetic variant of serum albumin. Science, N.Y. 153, 1664-6.

Porta, F., Boccato, P., Bonazz, L., Bozzetti, E., Burlina, A., Fisauli, F., Galzigna, L., Marinucot, M., Ortali, V., Petrint, C., Ruffini, G. \& Tentori, L. (1973). Varianti dell'albumina sierica in 22 famiglie confrontate per mezzo dell'elettroforesi. Boll. Ist. Sieroter. Milanese. 52, 1.

Porta, F., Ruffini, G., Ortali, V. \& Fisauli, F. (1972). Alloalbuminemia. Analytical separation by electrophoretic procedure. Proc. Int. Symp. on Standardization in Haemat. and Clin. Path. Foggia, Italy: S. Giovanni Rotondo.

Salzano, F. M., Neel, J. V. \& Maybury-Lewis, D. (1967). Further studies on the Xavante Indians. I. Demographic data on two additional villages: genetic structure of the tribe. Am. J. Hum. Genet. 19, 463.

TANIS, R. J., NeEL, J. V., Dovey, H. \& MoRRow, M. (1973). The genetic structure of a tribal population, the Yanomama Indians. IX. Gene frequencies for 17 serum protein and erythrocyte enzyme systems in the Yanomama and five neighbouring tribes; Nine new variants. Amer. J. Hum. Genet. (in the press).

WeItKamp, L. R. (1973). The contribution of variations in serum albumin to the characterization of human populations. Israel Med. J. Sci. (in the press).

Weitkamp, L. R. \& NeEL, J. V. (1972). The genetic structure of a tribal population, the Yanomama Indians. IV. Eleven orythrocyte enzymes and summary of protein variants. Ann. Hum. Genet. (Lond). 35, 433.

Weitkamp, L. R., Salzano, F. M., Neel, J. V., Porta, F., Geerdink, R. A. \& Tánoky, A. L. (1973). Human serum albumin: twenty-three genetic variants and their population distribution. Ann. Hum. Genet. (Lond.) 36, 381.

Weitkamp, L. R., Shreffler, D. C. \& SaAve, J. (1969). Serum albumin variants in New Guinea indigenes. Vox. Sang. 17, 237.

\section{APPENDIX}

Table 1. Comparative mobility of 23 types of 'monomeric' human serum albumin variants in three starch-gel systems

\begin{tabular}{|c|c|c|c|c|c|c|}
\hline & \multicolumn{2}{|c|}{ Albumin types } & \multirow[b]{2}{*}{ Population } & \multicolumn{3}{|c|}{$\begin{array}{l}\text { Electropnoretic separation } \\
(\mathrm{mm}) \text { at gel buffer } \mathrm{pH}^{1}\end{array}$} \\
\hline & Previous series ${ }^{2}$ & Present series & & $5 \cdot 0$ & $6 \cdot 0$ & 6.9 \\
\hline I & & $\operatorname{RS} I^{3}$ & Somali & $16 \cdot 5$ & $8 \cdot 0$ & $3 \cdot 0$ \\
\hline 2 & Pollibauer & $\begin{array}{l}\text { RS III } \\
\mathrm{MI} / \mathrm{MI}^{44} \\
3366^{5}\end{array}$ & $\begin{array}{l}\text { - } \\
\text { Somali } \\
\text { Italian } \\
\text { French }\end{array}$ & $\begin{array}{l}16 \cdot 5 \\
16 \cdot 0 \\
17 \cdot 0 \\
17 \cdot 0\end{array}$ & $\begin{array}{l}8 \cdot 0 \\
8 \cdot 0 \\
8 \cdot 0 \\
8 \cdot 0\end{array}$ & $\begin{array}{l}5 \cdot 0 \\
4 \cdot 5 \\
5 \cdot 0 \\
4 \cdot 5\end{array}$ \\
\hline 3 & Belém I & - & - & 14.5 & 9.5 & $5^{\circ} \circ$ \\
\hline & B (family Io) & $\begin{array}{l}2262^{6} \\
2836^{6} \\
2968^{6}\end{array}$ & $\begin{array}{l}\text { French } \\
\text { French } \\
\text { French }\end{array}$ & $\begin{array}{l}13.5 \\
13.5 \\
13.5 \\
13.5\end{array}$ & $\begin{array}{l}7 \cdot 0 \\
7 \cdot 0 \\
7 \cdot 0 \\
7 \cdot 0\end{array}$ & $\begin{array}{l}7 \cdot 5 \\
8 \cdot 0 \\
8 \cdot 0 \\
7 \cdot 5\end{array}$ \\
\hline 4 & & $\begin{array}{l}3006^{6} \\
4014^{5} \\
34249^{5} \\
\text { SO/SO (Gi.Pa). }{ }^{4} \\
\text { VR/VR (Ag. Di. })^{4} \\
\text { VR/VR (Bi. Gi.. } \\
\text { VR/VR (Pi. Al. })^{4}\end{array}$ & $\begin{array}{l}\text { French } \\
\text { French } \\
\text { French } \\
\text { Italian } \\
\text { Italian } \\
\text { Italian } \\
\text { Italian }\end{array}$ & $\begin{array}{l}13.5 \\
13.5 \\
13.5 \\
13.5 \\
13.5 \\
13.5 \\
13.5\end{array}$ & $\begin{array}{l}7 \cdot 0 \\
7 \cdot 0 \\
7 \cdot 0 \\
7 \cdot 0 \\
7 \cdot 0 \\
7 \cdot 0 \\
7 \cdot 0\end{array}$ & $\begin{array}{l}8 \cdot 0 \\
7 \cdot 5 \\
7 \cdot 5 \\
7 \cdot 5 \\
7 \cdot 5 \\
7 \cdot 5 \\
7 \cdot 5\end{array}$ \\
\hline 5 & Roma & - & - & 13.5 & $10 \cdot 0$ & $6 \cdot 5$ \\
\hline 6 & Gainesville (family 24) & $3433^{5}$ & French & $\begin{array}{l}13 \cdot 0 \\
13 \cdot 0\end{array}$ & $\begin{array}{c}7 \cdot 5 \\
7 \cdot 0(7 \cdot 5)\end{array}$ & $\begin{array}{c}5 \cdot 0 \\
4.5(5 \cdot 0)\end{array}$ \\
\hline 7 & Paris (family II) & - & - & 12.5 & $7 \cdot 0$ & 4.0 \\
\hline
\end{tabular}




\section{APPENDIX (cont.)}

\begin{tabular}{|c|c|c|c|c|c|c|}
\hline \multicolumn{3}{|c|}{ Albumin types } & \multirow[b]{2}{*}{ Population } & \multicolumn{3}{|c|}{ (mm) at gel buffer $\mathrm{pH}^{1}$} \\
\hline & Previous series* & Present series & & $5 \cdot 0$ & 6.0 & 6.9 \\
\hline 8 & Afghanistan & $\begin{array}{l}\text { NDH } 359^{7} \\
\text { NDH } 442^{7}\end{array}$ & $\begin{array}{l}\text { Hindu (India) } \\
\text { Jat Hindu (India) }\end{array}$ & $\begin{array}{l}10.5 \\
10.5 \\
10.5\end{array}$ & $\begin{array}{l}8 \cdot 0 \\
8 \cdot 0 \\
8 \cdot 0\end{array}$ & $\begin{array}{l}8 \cdot 0 \\
8 \cdot 0 \\
8 \cdot 0\end{array}$ \\
\hline 9 & Santa Ana & - & - & $7 \cdot 0$ & $4 \cdot 5$ & $6 \cdot 5$ \\
\hline IO & $\mathrm{SO} / \mathrm{BS}$ & - & 一 & 6.5 & $2 \cdot 5$ & $6 \cdot 0$ \\
\hline & & $\begin{array}{l}\mathrm{MI} / \mathrm{NO} \mathbf{I}^{4} \\
\mathrm{SO} / \mathrm{SO}(\mathrm{Do} . \mathrm{Fa} .)^{4}\end{array}$ & $\begin{array}{l}\text { Italian } \\
\text { Italian }\end{array}$ & $\begin{array}{l}7 \cdot 0 \\
6 \cdot 5\end{array}$ & $\begin{array}{l}2 \cdot 0 \\
2 \cdot 0\end{array}$ & $\begin{array}{l}6 \cdot 0 \\
5 \cdot 5\end{array}$ \\
\hline I I & Cartago & Etie $^{8}$ & $\begin{array}{l}\text { U.S. (Irish, Spanish and } \\
\text { French descent) }\end{array}$ & $\begin{array}{l}6 \cdot 5 \\
6 \cdot 5\end{array}$ & $\begin{array}{l}6 \cdot 0 \\
6 \cdot 0\end{array}$ & $\begin{array}{l}4 \cdot 0 \\
4 \cdot 0\end{array}$ \\
\hline & & VR/VR (Ci. Da.) ${ }^{4}$ & Italian & $6 \cdot 5$ & $6 \cdot 0$ & $4 \cdot 0$ \\
\hline 12 & & Xavante $^{9}$ & Xavante Indian (Brazil) & $4 \cdot 0$ & $\circ$ & o \\
\hline 13 & Pushtoon & - & - & $3 \cdot 5(4 \cdot 0)$ & $3 \cdot 5$ & $\begin{array}{l}\text { Broad } \\
(3 \cdot 0)\end{array}$ \\
\hline 14 & Cayemite & - & - & Smeared & $2 \cdot 0$ & $3 \cdot 0$ \\
\hline I 5 & Mexico & - & - & 3.5 & $3 \cdot 5$ & $4 \cdot 0$ \\
\hline I6 & Uinba & 一 & - & $3 \cdot 0$ & 0 & $\circ$ \\
\hline 17 & & Yanomama-2 $2^{10}$ & Yanomama Indian (Brazil) & o & o & $3 \cdot 0$ \\
\hline 18 & Medán & 一 & 一 & $3 \cdot 5$ & $\circ$ & Broac \\
\hline 19 & Máku & 一 & - & $5 \cdot 0$ & 3.0 & $7 \cdot 0$ \\
\hline 20 & $\begin{array}{l}\text { New Guinea (family } \\
\text { 27) and Reading } \\
\text { (family 28) }\end{array}$ & - & - & $6 \cdot 5$ & $6 \cdot 5$ & $3 \cdot 0$ \\
\hline & & $\begin{array}{l}\text { MAP } 6 / 27^{11} \\
\text { PAR }_{5}, \text { I }^{11,255^{12}} \\
\text { Westcott }^{13}\end{array}$ & $\begin{array}{l}\text { New Guinea indigene } \\
\text { New Guinea indigene } \\
\text { U.S. (English/Amerin- } \\
\text { dian) }\end{array}$ & $\begin{array}{l}6 \cdot 5 \\
6 \cdot 5 \\
6 \cdot 5\end{array}$ & $\begin{array}{l}6 \cdot 5 \\
6 \cdot 5 \\
6 \cdot 5\end{array}$ & $\begin{array}{l}3 \cdot 0 \\
3 \cdot 0 \\
3 \cdot 0\end{array}$ \\
\hline $2 \mathrm{I}$ & Makiritare-3 & - & 一 & $6 \cdot 5$ & $5 \cdot 0$ & $3 \cdot 0$ \\
\hline 22 & Naskapi & 一 & - & $7 \cdot 5$ & $7 \cdot 5$ & $6 \cdot 0$ \\
\hline 23 & Gent (family I 7) & 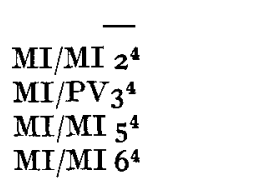 & $\begin{array}{l}\text { Italian } \\
\text { Italian } \\
\text { Italian } \\
\text { Italian }\end{array}$ & $\begin{array}{l}8 \cdot 5 \\
8 \cdot 5 \\
8 \cdot 5 \\
8 \cdot 5 \\
8 \cdot 5\end{array}$ & $\begin{array}{l}10.5 \\
11.0 \\
10.0 \\
10.5 \\
10.5\end{array}$ & $\begin{array}{l}7 \cdot 0 \\
7 \cdot 0 \\
7 \cdot 0 \\
7 \cdot 0 \\
7 \cdot 0\end{array}$ \\
\hline
\end{tabular}

1 Where two values are given the values were obtained on different gels. The first value is comparable to the values for the variants listed above it; the value in parentheses is comparable to the values for the variants listed below it.

2 Data and references for the variants representative of the 20 types of variants previously distinguished in these buffer systems are given in Weitkamp et al. (1973).
3 Ortali, in Porta et al. (1972).
4 Porta et al. (1973).
6 Fine (1970).
7 McDermid (I971 $a$ ).
- Fine (unpublished).
9 Weitkamp \& Neel (unpublished).
10 Tanis et al. (r 973 ).
8 Harris (unpublished)
12 McDermid (unpublished).
13 Peters (unpublished).
11 MeDermid ( 197 I $b$ ). 